\title{
Strategies used by nursing technicians to face the occupational suffering in an emergency unit
}

\author{
Estratégias utilizadas por técnicos de enfermagem para enfrentar o sofrimento ocupacional \\ em um pronto-socorro
}

Alessandra Bassalobre Garcia ${ }^{1}$, Maria do Carmo Fernandez Lourenço Haddad ${ }^{2}$, Mara Solange Gomes Dellaroza ${ }^{2}$, Fernanda Ludmilla Rossi Rocha ${ }^{3}$, Paloma de Souza Cavalcante Pissinati ${ }^{2}$

Objective: to understand the strategies used by nursing technicians in order to face the occupational suffering
in an emergency room. Methods: qualitative study carried out in an emergency room of a high complexity
hospital. Data were collected through semi-structured interviews with 12 nursing technicians. The analysis
relied on content analysis procedures. Results: respondents revealed as individual strategies to face suffering:
try not to get involved with the patient; separation between professional and personal life; and spirituality/
religion as support for coping. The collective strategies described by respondents included: action planning
for unexpected events in this unit; creating a supportive environment; and attempt to obtain recognition of
headship. Conclusion: individual and collective strategies were used consciously by workers and should be
encouraged by managers to face the occupational suffering. Descriptors: Nursing, Team; Occupational Health; Working Conditions; Burnout, Professional; Adaptation, Psychological.

Objetivo: compreender as estratégias utilizadas por técnicos de enfermagem para enfrentar o sofrimento ocupacional em um pronto-socorro. Métodos: estudo qualitativo, realizado em um pronto-socorro de um hospital de alta complexidade. A coleta de dados ocorreu por meio de entrevistas semiestruturadas, com 12 técnicos de enfermagem. A análise apoiou-se nos procedimentos de análise de conteúdo. Resultados: os entrevistados revelaram como estratégias individuais para enfrentar o sofrimento: tentativa de não se envolver com o paciente; separação entre vida profissional e pessoal; e espiritualidade/religião como suporte para o enfrentamento. As estratégias coletivas descritas pelos entrevistados compreenderam: planejamento das ações para imprevistos nesta unidade; criação de um ambiente de ajuda mútua; e tentativa de obter o reconhecimento da chefia. Conclusão: as estratégias individuais e coletivas foram utilizadas de forma consciente pelos trabalhadores e devem ser estimuladas pelos gestores para o enfrentamento do sofrimento ocupacional.

Descritores: Equipe de Enfermagem; Saúde do Trabalhador; Condições de Trabalho; Esgotamento Profissional; Adaptação Psicológica.

\footnotetext{
${ }^{1}$ Universidade da Carolina do Norte. Chapel Hill, NC, Estados Unidos.

${ }^{2}$ Universidade Estadual de Londrina. Londrina, PR, Brasil.

${ }^{3}$ Escola de Enfermagem de Ribeirão Preto, Universidade de São Paulo. Ribeirão Preto, SP, Brasil. 


\section{Introduction}

The way the individual relates to his work and its form of organization may bring out certain suffering, which must be managed, so that it becomes bearable and does not affect the individual's mental balance ${ }^{(1)}$. In the area of healthcare, and especially in nursing, the work can be emotionally draining due to proximity to situations of death intensified in units that assist unstable patients, such as emergency $\operatorname{rooms}^{(2)}$.

However, the work overload in urgency and emergency units with a large number of patients, coupled with the shortage of human and material resources, can make the work of the nursing staff less productive and humanized, compromising the performance of these professionals. In this context, some workers start to adopt attitudes of isolation and impersonality, manifested by low humanization and difficult interpersonal relationships, which are coping strategies to face these inadequate working conditions $^{(3-4)}$.

Thus, the work of the nursing staff in emergency rooms may become exhausting, marked by signs of overwork, fatigue and mental suffering. It is necessary to identify situations that cause suffering in these units in order to prevent that the quality of the offered care be compromised due to the imbalanced health of professionals $^{(5)}$.

In addition, other factors such as the devaluation, the lack of recognition by managers and other members of the work team, can also trigger dissatisfaction for workers ${ }^{(6)}$. Therefore, the conflict between work organization and the individual raises suffering that, in turn, requires coping strategies to mitigate impacts on the worker ${ }^{(1)}$.

The strategies are configured as levers to transform the adverse situations of work and are fundamental for individuals to be able to adapt to pressures, in addition to modify the very perception of the subject with respect to reality, making acceptable what was not. Although some theoretical lines are turned to the investigation of the unconscious strategies used by workers against the suffering, the present study was designed to reflect on the conscious actions, called coping strategies, which may emerge as a result of imbalances in the workplace ${ }^{(1)}$.

This theme is described in the theoretical framework of psychodynamics of work, which has as its main concern the understanding of the genesis and transformation of mental suffering linked to work organization ${ }^{(7)}$. According to this theory, the suffering is a state of struggle of the individual against conditions created by the organization or work processes, conflicting with his psychic functioning, and when there is no chance of adaptation between the organization and the wishes of this worker ${ }^{(1)}$.

It is noteworthy that the approach of this theoretical framework is geared towards the collective and not towards the individual alone. Therefore, one of the main assumptions of the theory refers to stimulate the practice of collective listening and group interventions with the purpose that workers develop team strategies for coping with the conditions imposed by the organization ${ }^{(8)}$.

Studies in psychodynamics of work in Brazil began in the 80s and followed the evolution of the theory, which currently seeks to understand the strategies and how the worker uses them to deal with suffering, reaching an equilibrium even under unfavorable conditions $s^{(7)}$. In this sense, it is important to understand these strategies.

Given the predisposition to the genesis of suffering in urgency and emergency units, it is expected that members of the nursing staff use coping strategies continuously to maintain mental and emotional balance. Thus, understanding the mechanisms used by these conscious workers against the suffering at work is essential, as these individuals represent a large part of the contingent of human resources of hospitals and work directly in patient care.

Therefore, the following question is raised: "what are the strategies adopted by workers of the 
nursing team to face suffering in a unit that care for urgencies and emergencies"? In order to address this problem, this study had the objective of understanding the strategies used by nursing technicians to face the occupational suffering in an emergency room.

\section{Methods}

This is a qualitative study carried out in the emergency room of a high complexity hospital, with 316 beds. This is a reference unit for the care of trauma and all urgency and emergency specialties, with hightech material resources and human resources with high level of expertise and training.

Still, patients treated at the place of study usually have severe impairment of health and high degree of dependence. Also, because this is a reference hospital for emergencies and gateway to the Unified Health System, this unit receives a great demand for care and is often working beyond its capacity.

The study population consisted of nursing technicians, from all work shifts and who worked in the emergency room. The following inclusion criteria were established: work in the unit for at least one year in order to be used to the daily dynamic routine, and acceptance to participate in the study by signing the Informed Consent. Subjects who were on vacations or on special leave during data collection were excluded.

The number of respondents was not determined before the collection because, in qualitative research, data collection occurs until sufficient convergence of lines is found to configure the investigated phenomenon, responding to the proposed objectives. The saturation of the content of the emerging data in the discourse allows the assurance that the information contains great diversity and coverage in relation to the reconstruction of the object of the studied material ${ }^{(9)}$. The non-probabilistic sampling by convenience was used for selection of participants , which comprises the inclusion of individuals that met the established criteria and were available to the researcher during the data collection period ${ }^{(10)}$.

Data collection was carried out from August to September 2010 through semi-structured interviews that would lastf 15 to 25 minutes, recorded and performed individually from the following guiding questions: "How do you develop your day-to-day work?"; "What are the feelings that arise during your work as nurse in the emergency room?"; "In what situations do you experience the feeling of pleasure?"; "In what situations do you experience the feeling of suffering?"; "What actions do you develop to deal with these feelings?"; and "Would you like to talk about something else?".

Subsequently, the interviews were transcribed without identifying the respondent. Therefore, participants' names were replaced by T1, T2, T3, etc. Also, codes were used to illustrate aspects of the dynamics of the transcription. For example, the sign (...) means that a fragment/part of the speech was excluded from the analysis and to illustrate the breaks occurred during the interview.

The framework used for analysis of the interviews was the Content Analysis Technique ${ }^{(11)}$ which identifies the nuclei that make up the speeches and give meaning to the investigated phenomenon. The manifested content of the message can be overcome by inference, reaching thus a deeper interpretation. The inference or induction by reasoning are presented by the categorical analysis, proposal for the analysis of content in three chronological and distinct stages: pre-analysis, exploration of the material and the processing of results.

For a discussion of the data, the reference of Work Psychodynamics was used ${ }^{(7)}$ because this approaches the strategies that an individual can use to address the suffering at work, as outlined above.

The study complied with the formal requirements contained in the national and international regulatory standards for research involving human beings. 


\section{Results}

Among participants, six (50.0\%) were female and six $(50.0 \%)$ were male, aged between 23 to 50 years, seven $(58.3 \%)$ reported being married, and $10(83.3 \%)$ had children. Time acting in nursing field varied between one and 32 years, with an average of 10.8 years, and the time working in the emergency unit, was between one and 13 years with an average of 2.9 years.

In this study, we identified that the nursing technicians were experiencing intense work, characterized by activities that required physical, psychomotor, cognitive and psychosocial skills, which generated psychological stress and often suffering. Thus, the subjects of this study revealed six coping strategies, individual or collective, to deal with this suffering.

Individual strategies were divided into three subcategories: keeping distant from the patient; separation between work and personal life; and spirituality/religion as support for coping. When it comes to collective strategies, these included the organization and planning to anticipate unforeseen events; mutual support and teamwork; and obtaining indirect acknowledgement. These subcategories are presented and discussed below.

\section{Keeping distance from the patient}

In this first subcategory, an attempt to not to get emotionally involved with the patient was observed, to avoid suffering, as shown in expressions (speeches) described below. Then, I'll take care of them ... but I wont get involved (T5). So, we follow this in the life of the patient, and like it or not, we have a bond with the patient, we try not have a very deep bond, but there is a bond with the patient (T9). But other than that, I try not to think, no, I do ... but ... like music, I hear but I do not listen to the lyrics, I do the service but I don't keep thinking why ... I think the healthcare makes us somewhat insensitive. Because, if you keep thinking of all the problems of others, you go mad, you end up... having problems, so I end up not thinking about it. (T10). You have to work that aspect, because if every suffering we pass you will cry with the patient, each death we cry again, it will be complicated. So you have to end up working yourself (T11).

\section{Separation between work and personal life}

In the second subcategory, a metalizing of the separation between professional and personal life was observed, when the worker builds in an ongoing effort the idea that there are two subjects: the working and the living, so that the suffering of the first do not extend to the life of the latter. Two people in one, that is the person who works at the hospital and the normal (name of respondent), from my house to the outside, because you need to have that separation, because otherwise you do not live... that suffering I had, it has to stay here, tomorrow I have a new structure, because otherwise ... I can not take care of another patient ... I turn on the car radio in the last ... for you to disconnect, because I try hard to differentiate my professional side from my personal side, I believe that people who are around me outside the hospital, or even inside, do not have nothing to do with the problems we have in our daily lives ... the best way that I turn off the hospital is with music, in those twenty minutes I get to my house, that's when I turn off the hospital (T4). Because you leave here, then you will keep thinking, and that's not good right? Here (in the hospital) I'm here. But, when I'm out there (outside the hospital), I'm there, so I do not mix things. (T5). We have to learn to be a little insensitive, otherwise you will bear too much weight ... I personally think so, that, it is their problem, I try to help at the time, but out of here, I forget. Hospital is hospital, home is home and that's it. My problem out there is my problem, a problem here inside, it's from here inside. I try not to put one close to the other (T10).

\section{Spirituality/religion as support for coping}

In this category, many speeches expressed the spirituality/religion as support for coping with daily suffering, which supported the understanding of the process of life, death and suffering. I look ... Biblical corners, what they talk about suffering, and ... keep the balance ... no use. Although I am sometimes sad, suffering, I have to hold on because the patient will need a word (T7). So what gives me a lot of strength is the 
spirituality, faith in God, I learned to have faith and put into practice what is most important. I have this to me, that there isn't anything that is impossible for God, and I tell this to patients, 'Look, you are suffering today, but regardless of the circumstances, the word of God says that we have thank everything, at all times thank God' (T9). Of course, we also ask for God's help, we are always asking, sometimes even in the unconscious, at the time that it is happening, we say 'Oh my God, give a help'... And it's amazing how He really is always at our side (T11).

\section{Organization and planning of work}

The statements in this category clearly demonstrated an routine typical of the work in an emergency room, consisting of a plan of action to advance preparation of unforeseen events in the unit. This planning consists of a collective strategy of defense, since it involves, besides the worker, his patients, colleagues, supervisors and other members of the multidisciplinary team. And I always try ... to arrive early and receive the call, know what is happening with the patient, so I may kind of create a work plan (T6). You look the most severe cases, check if any of them might have some complications ... then I do my planning ... checked signs, maintain a good breathing pattern in critically ill patients, I avoid a complication in my shift (T8). To make a plan, see what is the patient's priority, and be aware of his general state ... I think it's important ... well ... I always try to be psychologically prepared because we do not know what we will face in the emergency room (T9).

\section{Mutual support and teamwork}

Due to the complexity and instability existing in the environment of the emergency room, workers reported to support each other, because they understand that at any time, they may also need immediate assistance. This dynamic is configured as a collective coping strategy, through which the individual seeks to minimize the work load, as shown in the following statements of the participants ...I try to help others, because tomorrow I am the one who will have a complicated patient ... I am collaborating in order to have collaboration (T1). But with the team, I try to help everyone else ... the colleague, at some point, someone will help you (T2). If there is a complication, you have to be prepared, and it's not with me, the complication, but it is with the colleague, so ... when there is a complication, we have to help (T3). We know that this schedule is not fixed, you know that today you are in a place, but tomorrow you may be in another, tomorrow it may be you, then you end up working very much in a teamwork spirit, really (T7). Here in the emergency room, the more united staff is the morning shift because one helps the other, one assists in the bath, one does something for the other and this contributes to the development of work to be faster, more agile. There is no much trouble when a colleague is helping the other (T8).

\section{Obtaining acknowledgment from the leadership}

The last category refers to the attempt of nursing technicians to obtain acknowledgement from nursing leaders, indirectly, through dialogues that induce the feedback or bring some return on the result of the work done. It's just that ... in the day-to-day work, we realize that when you ask for something, the boss listens to you ... I try not to be asking for leaves ... if I'm asked to substitute, I do it , if I'm asked to do extra hours, I do regardless of time ... so I think that, if the boss hears you ... it's because he is satisfied with you ...... if he listens to you ... it's because he thinks you in a way. .. deserve that (T5).

\section{Discussion}

This study portrayed the occupational suffering experienced by workers in a unit of the emergency room of a teaching hospital. Thus, the uniqueness of speech does not allow for generalizing results. In addition, the composition of the sample, by individuals belonging only to the technical category of nursing, limited the understanding of the phenomenon from the experiences of other professionals such as nurses.

The result of the content analysis of interviews showed that the individual strategies were more related to the experience of the worker in face of the conditions of patients, while the collective were linked to the work process in the unit. The former are understood as mental processes, through which the 
individual seeks to modify or minimize the perception of the reality that makes him suffer, existing even without the mandatory presence of the situation that generated the conflict. When it comes to collective strategies, these are related to external conditions and are able to be maintained in the consensus of a group of workers ${ }^{(12)}$.

Keeping a distance from situations of illness or death beyond control and that trigger feelings of helplessness and grief has been observed as an escape strategy among hospital nurses. This way, workers adopt some behaviors observed in day-to-day, such as trying to spend less time with the patient, which actually reflects an attempt to avoid suffering ${ }^{(13)}$.

In clinical pain management, workers use the "distance" as a coping strategy, especially when they do not have specific training for that ${ }^{(14)}$. Similarly, the experience of a situation of death is a difficult task for nursing professionals, who are trained to save lives and may have difficulty accepting their finitude ${ }^{(15)}$.

Moreover, the attempt to control emotions that emerged from the problems experienced was evident. Thus, respondents used the self-control, which can be a strategy for dealing with suffering, or make it manageable, so that this does not exceed the tolerable level ${ }^{(16)}$.

It is noteworthy that the separation between personal and professional life proved to be a necessary strategy so that the employee does not use his free time with concerns arising from their employment practice. Although there is no formula to use to achieve this division, the individual assumes that there is a world for work and another for his life in which he moves daily and he sets a distance between them in order to alleviate the wear and tear of everyday work ${ }^{(17)}$.

Some nursing workers had adopted also strategies such as self-control, social support and escape-avoidance, beyond the setting the distance, to relieve stress from work. Therefore, by controlling himself or separating the professional who feels and suffers in his relationships with work and patients, the individual alleviates the suffering experienced in the emergency room ${ }^{(14)}$.

Participants also expressed the pursuit of religion or spirituality to accept the situations experienced. It stands out that religion acts as a support system, capable of minimizing the suffering and powerlessness arising from the care of critically ill patients or at risk of death. This is an attitude adopted against the pain of the neighbor ${ }^{(13,16)}$.

In face of the intensive pace of work of the unit in study, and the unpredictability discussed above, workers cannot work isolated from each other. They tend to seek the help of colleagues. The feeling of mutual aid requires acknowledgement of the importance of teamwork and interpersonal skills to ease tensions and contribute to the proper functioning of the unit. In addition, the establishment of ties with team members relieve tensions, promote dialogue and encourage individuals to conduct their activities ${ }^{(7,13)}$.

It is noteworthy that collective strategies become relevant as their absence could lead to a lack of motivation, wear in interpersonal relationships and increased psychic load at work. Still, they are essential for strengthening the group, since collective requirements are projections of individual needs ${ }^{(18)}$.

Participants said to pursue the relationship with their supervisors as a way to face the suffering at work. Therefore, this relationship must be based on the acknowledgement and appreciation of their work, in order to disclose the value that managers attribute to the work performed by the nursing staff. This relationship will build a true meaning of work which, in turn, motivates the worker to transform situations of suffering into pleasure ${ }^{(19-20)}$.

\section{Conclusion}

The team used individual and collective strategies to overcome the suffering caused by contact with the suffering of others, with the unpredictability of the work process, in addition to seeking the appreciation of their work through acknowledgement. It is necessary that managers know these strategies so 
that they can empower those in their teams and thus reduce the consequences of suffering when these are inevitable.

For this, the view that the issues surrounding human resources go beyond meeting the demands of hiring and staffing is necessary, as well as overcoming the vision of classical hospital culture, marked by impersonal and technical attitudes. The appreciation of the subjectivity of workers becomes important to understand the process of suffering that they experience in their professional practice, and the strategies they have adopted to minimize wear.

It is noteworthy that the use of coping strategies is essential to get a psychic balance at work and they should be used so that the pleasure may outweigh the suffering at work. Therefore, workers also need to understand how to manage the dissatisfaction of situations in order to identify strategies that provide satisfaction.

\section{Collaborations}

Garcia $\mathrm{AB}$ contributed to the conception and design of the project, analysis and interpretation of data, and writing the article. Haddad MCFL, Dellaroza MSG and Rocha FLS contributed to the writing of the article, relevant and critical review of the intellectual content. Pissinati PSC contributed to the writing of the article and to the final version to be published.

\section{References}

1. Dejours C. A loucura do trabalho: estudo de psicopatologia do trabalho. $6^{\underline{a}}$ ed. São Paulo: Cortez- Oboré; 2015.

2. Garcia AB, Dellaroza MSG, Haddad MCL, Pachemshy LR. Prazer no trabalho de técnicos de enfermagem do pronto-socorro de um hospital universitário público. Rev Gaúcha Enferm. 2012; 33(2):153-9.

3. Melo SF, Munari DB, Silva AP, Brasil VV. Revisão integrativa acerca do trabalho de enfermagem em unidades de urgência e emergência. Cuid Arte Enferm. 2011; 5(1):52-61.
4. Simões JS, Otani MAP, Siqueira Júnior AC. Estresse dos profissionais de enfermagem em uma unidade de urgência. Regrad. Rev Eletr Graduação UNIVEM [Periódico na Internet]. 2015 [citado $2015 \mathrm{dez}$ 9]; 8(1):75-95. Disponível em: http://revista. univem.edu.br/index.php/REGRAD/article/ view/862/403

5. Garcia AB, Dellaroza MSG, Gvozd R, Haddad MCL. $O$ sofrer no trabalho: sentimentos de técnicos de enfermagem do pronto-socorro de um hospital universitário. Ciênc Cuid Saúde. 2013; 12(3):41623.

6. Kessler AI, Krug SBF. Do prazer ao sofrimento no trabalho da enfermagem: o discurso dos trabalhadores. Rev Gaúcha Enferm. 2012; 33(1):49-55.

7. Dejours C, Abdoucheli E, Jayet C. Psicodinâmica do trabalho: contribuição da escola dejouriana à análise da relação prazer, sofrimento e trabalho. São Paulo: Atlas; 2014.

8. Traesel ES, Merlo ARC. Trabalho imaterial no contexto da enfermagem hospitalar: vivências coletivas dos trabalhadores na perspectiva da psicodinâmica do trabalho. Rev Bras Saúde Ocup. 2011; 36(123):40-55.

9. Gomes R. Análise e interpretação de dados de pesquisa qualitativa. In: Minayo MCS, Deslandes SF, Gomes R. Pesquisa social: teoria, método e criatividade. Petrópolis: Vozes; 2007. p.79-108.

10. Polit DF, Beck CT. Fundamentos da pesquisa em enfermagem: avaliação de evidências para a prática de enfermagem. Porto Alegre: Artmed; 2011.

11. Bardin L. Análise de conteúdo. Lisboa: Edições 70; 2011.

12. Dejours C. 0 fator humano. Rio de Janeiro: FGV; 2007.

13. Martins JT, Robazzi MLCC. Estratégias defensivas utilizadas por enfermeiros de unidade de terapia intensiva: reflexão na ótica dejouriana. Ciênc Cuid Saúde. 2012; 11(supl):39-46.

14. Negromonte MRO, Araújo TCCF. Impact of the clinical management of pain: evaluation of stress and coping among health professionals. Rev Latino-Am Enfermagem. 2011; 19(2):238-44. 
15. Rockembach JV, Casarin ST, Siqueira HCH. Morte pediátrica no cotidiano de trabalho do enfermeiro: sentimentos e estratégias de enfrentamento. Rev Rene. 2010; 11(2):63-71.

16. Moreno FN, Gil GP, Haddad MCL, Vannuchi MTO. Estratégias e intervenções no enfrentamento da síndrome de burnout. Rev Enferm UERJ. 2011; 19(1):140-5.

17. Mutti CF, Padoin SMM, Paula CC. Espacialidade do ser-profissional-de-enfermagem no mundo do cuidado à criança que tem câncer. Esc Anna Nery. 2012; 16(3):493-9.
18. Mininel VA, Baptista PCP, Felli VEA. Psychic workloads and strain processes in nursing workers of Brazilian university hospitals. Rev Latino-Am Enfermagem. 2011; 19(2):340-7.

19. Bendassolli PF, Soboll LAP, organizadores. Clínicas do trabalho. São Paulo: Atlas; 2011.

20. Sprandel LIS, Vaghetti HH. Valorização e motivação de enfermeiros na perspectiva da humanização do trabalho nos hospitais. Rev Eletr Enf [periódico na Internet]. 2012 [citado $2015 \mathrm{dez}$ 9]; 14(4):794802. Disponível em: http://www.fen.ufg.br/ revista/v14/n4/v14n4a07.htm 